КРЕАТИВНІСТЬ МАЙБУТНЬОГО ВЧИТЕЛЯ

В ЗАГАЛЬНІЙ ТЕОРІЇ ТВОРЧОСТІ: ТЕОРЕТИЧНИЙ АСПЕКТ

\title{
FUTURE TEACHER'S CREATIVITY IN GENERAL CREATIVE THEORY: A THEORETICAL ASPECT
}

У статті висвітлено сучасне фрілософрськоосвітнє розуміння френоменів креативності та творчості, висвітлена потреба в застосуванні креативних форм, методів навчання, які розвивають здатність до оригінальної думки та креативної дії, а також необхідність підготовки майбутніх учителів, у тому числі й математики, до зазначеноі діяльності.

Представлено результати аналізу численних освітніх документів як нашої держави, так і іноземних країн, у тому числі й Ради Європи, у яких йдеться про те, що головною рушійною силою розвитку є реалізація креативного потенціалу нації.

Розглянуто різні погляди педагогів і психологів на проблему трактування вказаних понять. Охарактеризовані визначення понять «творчість» $i$ «креативність», які використовуємо у рамках власного дослідження.

у цій публікації творчість визначено як характеристику діяльності суб'єкта, результатом якої є створення нових матеріальних і духовних цінностей, передбачаючи наявність у суб'єкта здібностей, мотивів, знань і умінь, завдяки яким і створюється такий продукт, що вирізняється унікальністю, новизною та оригінальністю.

Креативність охарактеризована як: інтегративна сукупність якостей особистості, які спонукають до творчої діяльності; творчі здібності особистості, котрі проявляються в різних сфрерах активності й розглядаються як відносно незалежний фрактор обдарованості та є умовою самореалізації особистості; здатністьгенеруватинові, оригінальні ідеї в межах тематики; творча здібність, необхінна мотиваційна основа творчості. Зроблено висновок про важливість формування здібностей людини до креативності та творчості в умовах розвитку сучасного суспільства, про необхідність розвитку креативності майбутніх учителів, у тому числі й математики, в процесі їхньої фрахової підготовки в умовах нової української школи, інклюзивної освіти, фрормування конкурентоздатної, мобільної особистості тощо, яка здатна не лише застосовувати на практиці знання, вміння і навички, а й приймати оригінальні та нестандартні рішення в ситуаціях, що виникають у профресійній діяльності педагога. Ключові слова: креативність майбутнього вчителя, творчість, нова українська школа, розвиток креативності, педагогічний університет, фрахова підготовка майбутніх учителів.

Contemporary philosophical and educational understanding of the phenomena of creation and creativity is highlighted in the article, the need for the use of creative forms, teaching methods that develop the capacity for original thought and creative action, as well as the need to prepare future teachers, including mathematics, are highlighted. The results of the analysis of numerous educational documents of our state as well as of foreign countries, including the Council of Europe, are presented.

Different views of teachers and psychologists on the problem of interpretation of these concepts are considered. The definitions of "creation" and "creativity" used in our own research are characterized.

In this publication, creativity is defined as a characteristic of the activity of the subject, the result of which is the creation of new material and spiritual values, assuming the presence of the subject's abilities, motives, knowledge and skills, which creates a product that is unique, novelty and originality.

Creativity is characterized as: an integrative set of personality traits that inspire creative activity; creative abilities of the personality, which are manifested in different spheres of activity and is considered as a relatively independent factor of talent and is a condition for self-realization of the personality; the ability to generate new, original ideas within a topic; creative ability, the necessary motivational basis of creativity.

The conclusion is made about the importance of forming a person's ability to creativity and creation in the conditions of modern society development, the need to develop the creativity of future teachers, including mathematics, in the process of their professional training in the conditions of a new Ukrainian school, inclusive education, formation of a competitive, mobile personality etc., which is capable not only to put into practice knowledge, skills and skills, but also to make original and non-standard decisions in situations that arise in the professional activity of teaching.

Key words: creativity of future teacher, creation, new Ukrainian school, development of creativity, pedagogical university, professional training of future teachers. педагогічного університету

імені Олександра Довженка
Постановка проблеми у загальному вигляді та її зв'язок з важливими науковими чи практичними завданнями. Сучасний етап розвитку вищої освіти висуває нові вимоги до підготовки студентів закладів вищої освіти, в тому числі й педагогічних, які полягають у тому, що набуття лише предметних знань уже не є достатнім для того, щоб скласти конкуренцію на ринку праці. Дослідження Всесвітнього економічного фроруму продемонструвало, що до 2020 року креативність стане однією з трьох найважливіших навичок, які роботодавці цінуватимуть у своїх працівниках. Тому виникає потреба у фрормуванні і розвитку таких здібностей особистості, які розкривають їі індивідуальні якості, інтелектуальні можливості й творчий потенціал.

Нові цінності та орієнтири освіти (індивідуально-особистісний підхід у навчанні, суб'єктсуб'єктні відносини вчителя та учнів тощо), а також сучасні досягнення науки багато в чому визнача- 
ють вибір технологій, яким педагоги все частіше віддають перевагу на цьому етапі розвитку освіти [19, с. 184-196].

Виникає потреба у застосуванні креативних форм, методів навчання, які розвивають здатність до оригінальної думки та креативної дії. Тому одним із пріоритетних напрямів політики України $€$ турбота про обдаровану та талановиту молодь, у тому числі й студентів педагогічних закладів освіти, її творчий, інтелектуальний, духовний та фрізичний розвиток.

Звідси найважливішим завданням освітніх систем $€$ забезпечення творчого розвитку особистості, про що наголошується у численних освітніх документах нашої держави. Зокрема, у Державній національній програмі «Освіта» (Україна XXI століття) одним зі стратегічних завдань окреслено створення умов для формування освіченої, творчої особистості громадянина, реалізації та самореалізації його природних задатків і можливостей в освітньому процесі [5].

У Національній доктрині розвитку освіти зазначено: «Держава має забезпечувати <...> розвиток творчих здібностей і навичок самостійного наукового пізнання, самоосвіти і самореалізації особистості» [17].

На ролі креативності, як особливості професійної підготовки, наголошується у Законі України «Про вищу освіту» та в декларації Всесвітньої конференції 3 вищої освіти ЮНЕСКО «Вища освіта у XXI столітті: бачення та дії» (1998р.) [12], що розглядає креативність як інноваційний навчальний підхід.

Нині, у час стрімких змін вищої освіти, особливої актуальності набуває питання розвитку педагогічної креативності особистості, що $є$ одним із базових компонентів не лише вітчизняних стратегічних освітніх указаних вище документів, а й визначено Радою ЄС одним із чотирьох завдань у рамках основної стратегії європейського співробітництва в галузі освіти і професійної підготовки до 2020 року [4].

Доктрина збалансованого розвитку «Україна 2030» одним із пріоритетів вбачає «запропонувати нову соціально орієнтовану модель економічного розвитку, де найвищою цінністю є Людина, а головною рушійною силою розвитку - реалізація креативного потенціалу нації» [1].

Згідно 3 Лісабонською декларацією про європейські університети (від 2010 р.), основна мета створити нові та удосконалити наявні університети Європи як інституційне середовище, що сприяє розвитку творчості, креативного мислення та інновацій.

Відповідно до компетенцій, визначених експертами у 2017 р. на Світовому економічному форумі в Давосі, креативне мислення входить до ТОП-5 компетенцій найближчого десятиліття [16].
У сучасній освіті креативність педагога виступає як один з провідних фракторів успішності навчання. Креативність стає тією якістю, що забезпечує особистості можливість адаптуватися до мінливих умов життя і $€$ запорукою успіху людини у професійній діяльності. Креативність є також важливим чинником розвитку особистості, що визначає їі готовність змінюватися і відмовлятися від стереотипів [6].

На думку В. Павленко, педагогічною аксіомою сьогодення має бути теза: щоб успішно розвивати креативність школярів, сучасний учитель сам мусить бути креативною особистістю, прагнути до подолання в собі сили шаблону та фрормальності у викладанні навчального матеріалу» [18]. Тому головною метою педагогічної освіти нині стає підготовка компетентного, кваліфрікованого, креативного випускника, який здатний не лише застосовувати на практиці знання, вміння і навички, а й приймати оригінальні та нестандартні рішення в ситуаціях, що виникають у профресійній діяльності, що розглядаємо як особисті креативні якості педагога, спроможного діяти в умовах, які висуває до нього нова українська школа.

Аналіз останніх досліджень і публікацій. Навколо цього френомена точилися численні суперечки. Окремі покоління психологів, їхні наукові школи взагалі заперечували існування креативності як самостійної психологічної характеристики.

Понад півстоліття проблема креативності цікавила як зарубіжних, так і вітчизняних учених. Незважаючи на різноманітність підходів, визначають низку спільних поглядів учених щодо аналізованого феномена. Так, дослідники розглядають креативність як: загальну здатність до творчості (Л. Єрмолаєва-Томіна, С. Сисоєва, О. Ярошинська, Л. Байтімерова, В. Дружинін, Л. Пузеп, О. Кононко, О. Куцевол, В. Фрицюк, І. Подорожна, О. Приходько, Л. Виготський, К. Батовріна, К. Корнолович, С. Попек, В. Лімонт, Й. Кауфман); властивість особистості (Дж. Гілфорд, Е. Торренс, Є. Гергель); здатність особистості виходити за межі заданої ситуації, створювати оригінальні цінності (Ф. Баррон, Д. Богоявленська, С. Медник, В. Моляко, В. Сластьонін, Л. Байтімерова, Л. Пузеп, О. Кульчицька, І. Гриненко, О. Дунаєва, Н. Добровольська, Н. Вишнякова, І. Шахіна, Л. Виготський, Е. Фромм); процес прояву власної індивідуальності (О. Яковлєва, О. Войтенко, К. Шмідт); обов'язкову характеристику представника педагогічної професії (О. Антонова, С. Сисоєва, О. Куцевол, І. Подорожна, А. Шадріна, І. Гриненко, О. Дунаєва, А. Морозов, В. Фрицюк) [18].

Виділення не вирішених раніше частин загальної проблеми. Попри досить велику кількість досліджень і публікацій, проблема креативності й нині не втратила актуальності, оскільки й досі ще немає чітко визначеної структури, не 
розроблені теоретичні і методичні засади її розвитку. Особливої необхідності, на нашу думку, проблема розвитку креативності вчителів-предметників набуває в умовах нової української школи, інклюзивної освіти, фрормування конкурентоздатної, мобільної особистості тощо. У цій публікації ми розглянемо погляди вчених, у тому числі й сучасних, на визначення понять «творчість» і «креативність» і ссрормулюємо власні визначення цих понять, які будемо використовувати в рамках нашого дослідження.

Формулювання цілей статті (постановка завдання). Метою статті $€$ визначення феноменів творчості й креативності в сучасному науковому дискурсі. Завдання - проаналізувати погляди педагогів і психологів щодо френоменів творчості й креативності, сорормулювати визначення цих понять у рамках власного дослідження.

Виклад основного матеріалу дослідження. Поняття «творчість» у психологічній літературі часто ототожнюють 3 поняттям «креативність», вживаючи ці терміни як синоніми. Аналіз психолого-педагогічної літератури показує, що загальноприйнятого визначення поняття «креативність» натепер немає.

Зазначимо, що в англійській мові слово «креативність» (від лат. creatio - створення) є полісемічним. Інколи його перекладали як «творчісність», тобто те, що відображає творчі прагнення і можливості людини.

У англомовних психологічних джерелах цим терміном позначають те, що має безпосереднє відношення до створення нового, досі не існуючого, і також сам процес творення, його продукт і фактори здійснення [15, с. 33]. Саме тому багато визначень сутності творчості містять ознаки, які, на наш погляд, можна віднести до визначень креативності. Часте змішування термінів «креативність» і «творчість», їх уживання як синонімів викликає потребу в розмежуванні цих понять.

Розглянемо сучасне фрілософрсько-освітнє розуміння френоменів творчості й креативності, у тому числі й педагога, та різні точки зору вчених на визначену проблему.

Так, у далекі часи Платон відносив до творчості все створене людиною: «...Усе, що викликає перехід 3 небуття у буття - творчість...». В інтерпретації І. Канта творчість $€$ чимось рідкісним і вражаючим, це таємниця: «Новизна стає тут джерелом і засобом пожвавлення уваги. Творчість усе більше суб'єктивується і з універсальної перетворюється на окрему здібність людини» [10, с. 29].

Б. Спіноза пов'язує творчість безпосередньо 3 діяльністю людини і переконаний, що вона $€$ сутнісною характеристикою буття. Як перехід від старої дійсності до нової під дією продуктивної активності творчого «Я» творчість визначає І. Фіхте [23].
3. Фрейд вважає творчу активність результатом сублімації статевого потягу на іншу сферу діяльності [26].

А. Адлер уявляє творчість результатом компенсації комплексу недостатності [2].

К. Юнг представляє творчість як прояв архетипів колективного без свідомого [27, с. 7].

Філософрський енциклопедичний словник дає таке визначення: «Творчість - продуктивна діяльність за мірками свободи та оновлення, коли зовнішня детермінація людської активності змінюється внутрішньою самовизначеністю. Елементи творчості притаманні людській діяльності взагалі, але як окремий різновид діяльності творчість характеризується продукуванням нових результатів» [25].

Б. Ананьєв охарактеризував творчість як специфрічну людську діяльність, принципово нову, що перетворює дійсність. Сьогодення вимагає, щоб кожен учитель став активним перетворювачем дійсності [3, с. 18].

В енциклопедії освіти подано: «Творчість школярів - це діяльність, результат якої характеризується суб'єктивною новизною, оскільки вона пов'язана із засвоєнням нових знань і розв'язуванням різноманітних задач у процесі навчально-виховної роботи в школі та на позашкільних заняттях. Основний закон дитячої творчості, сфрормульований видатним психологом Л. Виготським, твердить, що її цінність слід бачити не в результаті, не в продукті творчості, а в самому процесі» [8, с. 899].

На думку психолога О. Кульчицької, творчість - це суто людська діяльність. «Це не лише створення суспільно значущого продукту, творчістю можна назвати всі ті «відкриття», які людина робить особисто для себе. Творчими є майже всі психічні процеси, за винятком, може, автоматизованих дій» $[13$, с.10].

Деякі вчені (М. Данилов, В. Кузін, А. Люблінська) схиляються до думки, що творчість є складною інтегративною діяльністю, вона обов'язково має свою певну структуру та включає в себе певні процеси творчої діяльності: постановка задачі, формулювання задуму, реалізація задуму і продукт творчої діяльності [11].

С. Медник у своїх дослідженнях вважає, що у творчому процесі присутні як конвергентна, так і дивергентна складові частини. Психолог вважає, що суть творчості - в спроможності переборювати стереотипи на кінцевому етапі розумового синтезу, у широті поля асоціацій [27, с. 23].

Відомий психолог, науковець М. Гнатко стверджує, що творчістю слід називати ту активність, завдяки якій людина породжує нові, соціально значущі матеріальні і духовні цінності, проявляє потенційну та актуальну креативність $[9$, с. 6].

Таким чином, у своєму дослідженні розглядаємо творчість як характеристику діяльності 
суб'єкта, результатом якої $€$ створення нових матеріальних і духовних цінностей, передбачаючи наявність у суб'єкта здібностей, мотивів, знань і умінь, завдяки яким і створюється такий продукт, що вирізняється унікальністю, новизною та оригінальністю.

Аналізуючи підходи вчених до поняття креативності, констатуємо, що сучасна психолого-педагогічна наука розглядає це поняття в різних аспектах.

Першу десініцію креативності було введено відомим зарубіжним ученим, психологом Д. Сімпсоном у 1922 році, котрий стверджував, що креативністю $є$ здатність людини відмовитися від стеоретипних способів мислення, вміння руйнувати загальноприйнятий, звичайний порядок походження ідей під час мислення [14, с. 632].

Американський учений Джон Као у своїх дослідженнях трактував креативність як цілісний процес генерації ідей, їх розвитку та перетворення на цінності. Цей процес поєднує в собі те, що люди називають новаторством [14, с. 637].

Дж. Гілфрорд розробляє концепцію креативності, в якій він указав на принципове розходження між двома типами розумових операцій: конвергенцією і дивергенцією. Конвергентне мислення актуалізується в тому разі, коли людині, яка розв'язує задачу, потрібно на основі множини умов знайти єдине правильне розв'язання. Конкретних рішень може бути і декілька, але ця множина завжди обмежена. Дивергентне мислення визначається як «тип мислення, який рухається в різноманітних напрямах». Такий тип мислення припускає варіювання шляхів вирішення проблеми, призводить до несподіваних висновків і результатів. Дж. Гілфрорд вважав операцію дивергенції основою креативності як загальної творчої здібності [27].

У наукових роботах американського психолога Е. Торренса охарактеризовано поняття «креативність» як процес: 1) появи чутливості до проблем, десріциту знань, їх невідповідності, дисгармонії та ін.; 2) фріксації цих проблем; 3) пошуку рішень цих проблем, висунення гіпотез; 4) перевірок, змін і повторних перевірок гіпотез; 5) фрормулювання результату [20, с. 90].

М. Волах і Н. Коган, які вважаються послідовниками Дж. Гілорорда, внесли певні зміни щодо трактування креативності. Вони відкинули один із критеріїв креативності - точність. Учені відмовилися від обмеження часу, середовища конкуренції та єдиного критерію правильної відповіді. Вони вважають, що креативність та інтелект взаємопов'язані не тільки на рівні якостей особистості, але й на рівні цілісного пізнавального процесу [7, с. 190].

Р. Стернберг вважає креативними таких людей, якіздатні «купуватиідеїзанизькоюціноюіпродавати за високою». Креативність передбачає спроможність особистості йти на розумний ризик, готовність переборювати перешкоди, внутрішню мотивацію, толерантність до невизначеності, готовність протистояти думці оточення. Дотримуються аналогічних наукових поглядів щодо поняття креативності Т. Амабайл, Т. Любарт, К. Урбан, Дж. Хейс [24].

У словнику С. Гончаренка креативність визначена як особистісна характеристика, а саме як здатність висловлювати незвичайні ідеї, нетрадиційно мислити, швидко розв'язувати проблемні ситуації [21, с. 102].

С. Сисоєва розглядає креативність як фундамент творчої особистості, «детермінантою якої виступає творча активність індивіда», як сукупність творчих задатків, умінь особистості, що зумовлюють певний рівень і характер розвитку творчих якостей особистості, її пізнавальних процесів, мислення, знань, умінь і навичок із урахуванням певних об'єктивних умов. [22, с. 245].

Погляди науковців К. Батовріної, О. Куцевол, В. Дружиніна, О. Кононко, І. Подорожної, Л. Пузеп в основному збігаються у питанні визначення поняття «креативність». Автори розуміють її як здатність до творчості, яка проявляється в різних сорерах активності й розглядається як відносно незалежний фрактор обдарованості та $€$ умовою самореалізації особистості [15].

Аналіз і систематизація визначень і трактувань креативності показує, що не можна дати єдиного визначення цього явища, але їх можна об'єднати в окремі групи: 1) здатність до творчості, відмова від стереотипного мислення, певний рівень творчих здібностей і можливостей особистості; 2) здатність осмислювати та розуміти нове, не боятися відійти від звичного; 3) здатність до генерування ідей, уміння доводити їх до конкретного практичного результату; 4) креативність як найвищий рівень інтелектуальних можливостей особистості; 5) креативність - не талант особистості, вона $€$ цілісним процесом, а тому вимагає розвитку.

У нашому дослідженні, погоджуючись 3 думкою багатьох науковців, зокрема К. Батовріною, О. Куцевол, В. Дружиніним, О. Кононко, В. Павленко, розглядаємо креативність як: інтегративну сукупність якостей особистості, які спонукають до творчої діяльності; творчі здібності особистості, котрі проявляються в різних сфрерах активності й розглядається як відносно незалежний фрактор обдарованості та є умовою самореалізації особистості; здатність генерувати нові, оригінальні ідеї в межах тематики; творчою здібністю, необхідною мотиваційною основою творчості.

Висновки і подальші перспективи в цьому напрямі. У цій публікації нами визначено феномени творчості й креативності в сучасному науковому дискурсі, проаналізовано погляди педагогів і психологів щодо френоменів творчості й креативності, сфрормульовано визначення цих понять у рамках власного дослідження. Подальшу роботу в цьому напрямі дослідження вбачаємо в роз- 
робці системи розвитку креативності майбутніх учителів, зокрема математики, в процесі фрахової підготовки.

\section{БІБЛІОГРАФІЧНИЙ СПИСОК:}

1. ESSnet-CULTURE. European Statistical System Network on Culture. Фінальний звіт. URL: http:// ec.europa.eu.

2. Адлер А. Практика и теория индивидуальной психологии / пер. с нем., вступ. ст. А.М. Боковикова. Москва : Прогресс, 1995. 296 с.

3. Ананьев Б.Г. Экспериментальная и прикладная психология. Сб. ст. Ленинград. гос. ун-та. Ленинград : Изд-во ЛГУ, 1971. 158 с.

4. Бузовська Т.В. Розвиток педагогічної креативності як особливості професійної підготовки майбутніх учителів іноземної мови. Освіта та розвиток обдарованої особистості. 2014. № 8. С. 31-33.

5. Державна національна програма «Освіта» (Україна XXI століття). Київ : Райдуга, 1994. 61 с.

6. Дімітрова-Бурлаєнко С.Д. Ґенеза поняття «креативна компетентність» у контексті психологопедагогічних досліджень. Педагогіка та психологія. 2017. Вип. 58. С. 3-14.

7. Дружинин В.Н. Психология общих способностей. Санкт-Петербург : Питер, 2008. 358 с.

8. Енциклопедія освіти / наук. ред. В.Г. Кремень. Київ : «Юрінком Інтер», 2008. 1040 с.

9. Єрмола А.М. Креативність в освітньому моніторингу. Практична психологія та соціальна pобота. 2003. № 8. С. 71-74.

10. Кант І. Критика практичного розуму. Київ : Юніверс, 2004. 240 c.

11. Клепіков О.І., Кучерявий І.Т. Основи творчості особи. Київ : Вища школа, 2006. 296 с.

12. Князев Ю.П. Ключевые палеонтологические территории в списке всемирного наследия ЮНЕСКО. Грани познания : журнал. 2013. Август (№ 5). C. 21-27.

13. Кульчицька О.І. Творчі здібності та особливості їх прояву в дитячому віці. Обдарована дитина. Київ. 2000. № 1. C. 10-14.

14. Курочкина А.Ю. Исследования креативности: постановка проблемы экономики. Сб. науковых статей по итогам Международной научной конфреренции, Санкт-Петербург, 19-20 мая 2009 г. / под. общ. ред. профр. Н.А. Горелова, профр. О.Н. Мелькова. Москва : Изд-во «Креативная экономика», 2009. C. $630-639$

15. Куцевол О.М. Теоретико-методичні основи розвитку креативності майбутніх учителів літератури : монографія. Вінниця : Глобус-Прес, 2006. 348 с.

16. Лісабонська декларація (Університети Європи після 2010 року: різноманіття за єдності мети. Брюсель, 13 квітня 2007 року). URL: https://drive.google. com/open?id=0B jORfZbHWtINEpONW1.

17. Національна доктрина розвитку освіти України у XXI столітті. Педагогічна газета. 2001. № 7 (85).

18. Павленко В.В. Креативність: сутнісна характеристика поняття. Креативна педагогіка: наук.метод. журнал. Академія міжнародного співробітництва 3 креативної педагогіки «Полісся». Житомир, 2016. Вип. 11. С. 120-131.

19. Павленко В.В. Суб'єкт-суб'єктна взаємодія у навчально-виховному процесі Польщі. Людинознавчі студії : зб. наук. праць Дрогобицького державного педагогічного університету імені Івана Франка. Серія «Педагогіка» / ред. кол. М. Чепіль (гол. ред.) та ін. Дрогобич : Вид. відділ ДДПУ імені Івана Франка. Випуск 2/34 (2016). С. 184-196.

20. Перкинс Д.Н. Творча обдарованість як психологічне поняття. Суспільні науки за рубежем. Сер. Науковедення. 1988. № 4. С. 88-92.

21. Профресійна освіта : словник / уклад. С.У. Гончаренко та ін.; за ред. Н.Г. Ничкало. Київ : Вища школа, 2000. 380 с.

22. Сисоєва С.О. Педагогічна творчість : монографрія. Київ : Каравела, 1998. 150 с.

23.Спиноза Б. Избранные произведения, в 2 т. Т. 1 Москва : Госполитиздат, 1957. 1366 с.

24. Стернберг Р. Модель структуры интеллекта Гилсорда: структура без фрундамента. Основные современные концепции творчества и одаренности / под ред. Д.Б. Богоявленской. Москва : «Молодая гвардия», 1976.

25. Философия: энциклопедический словарь / Под ред. А.А. Ивина. Москва : Гардарики, 2004. 770 с

26. Фрейд 3. Введение в психоанализ : лекции. Москва : Наука, 1989. 453 с.

27. Яланська С.П. Психологія творчості : навчальний посібник. Полтава : ПНПУ імені В.Г. Короленка, 2014. 180 c. 